\title{
Penilaian Greenship GBCI dalam Penerapan Re-Use Material di Café Day N Nite Bandung
}

\author{
Agung Prabowo Sulistiawan', I Made Raka Arsana1, Deni Puji \\ Nurwanto $^{1}$, Anggia Septiani Hartoyo ${ }^{1}$ \\ 1. Program Studi Arsitektur, Fakultas Arsitektur dan Desain \\ Itenas, Institut Teknologi Nasional Bandung \\ Email: agung.prabowo@itenas.ac.id
}

\begin{abstract}
ABSTRAK
Penerapan penggunaan kembali barang bekas (reuse material) sebagai bahan bangunan di Indonesia menjadi sebuah upaya dalam mewujudkan arsitektur ramah lingkungan. Salah satu contoh penggunaan material bekas yaitu penggunaan material peti kemas atau kontainer bekas. Peti kemas bekas sangat mungkin dijadikan unit dasar dalam perencanaan dan perancangan arsitektur hunian maupun komersial. Peti kemas bekas mungkin bukan termasuk limbah yang merusak lingkungan, karena peti kemas bekas dapat digunakan kembali (reuse), dan didaur ulang (recycle). Oleh karena itu, material peti kemas yang digunakan kembali pada bangunan, menjadikan bangunan yang unik dan ramah lingkungan serta membantu melestarikan lingkungan. Tujuan dari penelitian ini adalah untuk mengidentifikasi dan menilai bangunan Cafe Day $n$ Nite Bandung yang menggunakan material peti kemas bekas berdasarkan kriteria Sumber dan Siklus Material pada Greenship Green Building Council Indonesia (GBCI). Dalam penelitian ini metodologi penelitian yang digunakan adalah metodologi kualitatif berupa survey lapangan dan wawancara. Analisa yang dilakukan merujuk pada kriteria Sumber dan Siklus Material menurut Greenship GBCI yang meliputi Refrigeran Foundamental, Penggunaan Gedung dan Material Bekas, Material Ramah Lingkungan, Penggunaan Refrigeran tanpa ODP, Kayu Bersertifikat, Material Prafabrikasi, dan Material Regional. Berdasarkan hasil analisa dapat disimpulkan bahwa Cafe Day n Nite Bandung memenuhi total presentase sebesar 79\% penilaian berdasarkan kriteria Sumber dan Siklus Material pada Greenshp GBCI.
\end{abstract}

Kata kunci: reuse material, peti kemas, ramah lingkungan

\begin{abstract}
The application of reuse of materials as building materials in Indonesia is an effort to create environmentally friendly architecture. One example of using used materials is the use of used container. Used containers are very likely to be used as a basic unit in planning and designing residential and commercial architecture. Used containers may not include waste that damages the environment, because used containers can be reused and recycled. Nonetheless, container materials that are reused in buildings can make a building unique and environmentally friendly and help preserve the environment.The purpose of this study is to identify and assess the Cafe Day $n$ Nite Bandung buildings that use used container materials based on the Sources and Material Cycle criteria at the Greenship Green Building Council Indonesia (GBCI). In this study, the research methodology used is a qualitative methodology in the form of field surveys and interviews. The analysis was carried out from the criteria for Source and Material Cycles according to the GBCI Greenship including Foundamental Refrigerants, Use of Building and Used Materials, Environmentally Friendly Materials, Use of Refrigerants without ODP, Certified Wood, Prefabricated Materials, and Regional Materials. Based on the results of the analysis, it can be concluded that Cafe Day $n$ Nite Bandung fulfills a total percentage of $79 \%$ of the assessment based on the Sources and Material Cycle criteria at Greenshp GBCI.
\end{abstract}

Keywords: reuse material, used container, environmentally friendly 


\section{PENDAHULUAN}

Di Indonesia, penerapan konsep bangunan ramah lingkungan mulai menjadi perhatian khusus. Konsep bangunan ramah lingkungan merupakan salah satu upaya penghematan energi yang dapat diterapkan pada suatu bangunan. Seiring dengan perkembangan bangunan hijau di Indonesia, Menteri Lingkungan Hidup telah mengeluarkan Peraturan Menteri Negara Lingkungan Hidup No. 8 tahun 2010 tentang Kriteria dan Sertifikasi Bangunan Ramah Lingkungan [1]. Adapun tujuan utamanya yaitu sebagai bentuk pelaksanaan dan pengelolaan pembangunan yang menerapkan prinsip lingkungan dan aspek penting dalam penanganan dampak perubahan iklim.

Lembaga Konsil Bangunan Hijau Indonesia atau Green Building Council Indonesia (GBCI) adalah lembaga mandiri (non government) yang sangat memperhatikan pembangunan berkelanjutan dan memiliki perangkat penilaian yang disebut Greenship [2]. Bangunan ramah lingkungan merupakan usaha untuk memperhatikan seluruh aspek desain mulai dari perancangan, eksekusi, pemilihan material, pencetakan, dan pendaurulangan setelah suatu produk dipakai.

Salah satu material yang dapat didaur ulang di Indonesia adalah material bekas peti kemas atau kontainer. Peti kemas bekas sangat mungkin dijadikan unit dasar dalam perencanaan dan perancangan arsitektur hunian maupun komersial. Peti kemas bekas mungkin bukan termasuk limbah yang merusak lingkungan, karena peti kemas bekas dapat digunakan kembali (reuse), dan didaur ulang (recycle).

Cafe Day $n$ Nite yang terletak di Mekar Wangi, Maribaya, Kabupaten Bandung adalah salah satu bangunan yang menggunakan reuse container atau penggunaan kembali peti kemas bekas pakai. Terdapat beberapa kelebihan dan kekurangan pada penggunaan material peti kemas bekas pakai sebagai fasad bangunan. Salah satu kelebihannya antara lain adalah ketebalan peti kemas cukup tebal menjadikan bagian dalam bangunan terasa hangat meskipun kondisi sekitar kawasan cukup dingin. Sementara itu, kekurangan menggunakan peti kemas bekas pakai adalah diperlukan perhatian khusus dalam proses konstruksi terutama dalam pengerjaan detail sambungan satu kontainer dengan kontainer lain diperlukan ketelitian agar tidak terjadi kebocoran.

\subsection{Arsitektur Hijau (Green Architecture)}

Arsitektur hijau adalah suatu pendekatan perencanaan bangunan yang berusaha untuk meminimalisasi berbagai pengaruh membahayakan pada kesehatan manusia dan lingkungan. Sebagai pemahaman dasar dari arsitektur hijau yang berkelanjutan, elemen-elemen yang terdapat didalamnya adalah lansekap, interior, yang menjadi satu kesatuan dalam segi arsitekturnya [3].

Arsitektur hijau timbul dari keprihatinan mengenai greenhouse effect yang merupakan akibat dari peningkatan polusi udara berasal dari industri manufaktur, transportasi, bangunan dan penggunaan energi berlebihan. Lebih jauh, konsumsi energi fosil dunia sebesar $50 \%$ bersumber dari kebutuhan energi bangunan. Sehingga arsitektur hijau bisa diartikan sebagai arsitektur yang berwawasan lingkungan dan berdasarkan keprihatinan mengenai konservasi lingkungan, efisiensi energi dan pendekatan pembangunan berkelanjutan [4].

\subsection{Arsitektur Ramah Lingkungan}

Dalam upaya menciptakan lingkungan yang berkelanjutan dan mengatasi krisis energi dan dampak dari pemanasan global maka muncul istilah arsitektur ramah lingkungan yang diterjemahkan melalui desain aktif dan pasif [5]. Kemudian, untuk mengurangi penggunaan energi diperlukan desain khusus antara lain penggunaan jendela yang efisien, insulasi pada dinding, plafon atau tempat masuknya aliran udara ke dalam bangunan gedung. Strategi lain desain bangunan surya pasif, sering dilaksanakan di bangunanbangunan rendah energi [6]. 
Bangunan ramah lingkungan merupakan usaha untuk memperhatikan seluruh aspek desain mulai dari perancangan, eksekusi, pemilihan material, pencetakan, dan pendaurulangan material setelah suatu produk dipakai.

\subsection{Sumber dan Siklus Material}

Greenship Green Building Council Indonesia (GBCI) terbagi atas enam kategori yang terdiri dari : (1) Tepat Guna Lahan - Appropriate Site Development (ASD), (2) Efisiensi dan Konservasi Energi - Energy Efficiency \& Conservation (EEC), (3) Konservasi Air - Water Conservation (WAC), (4) Sumber \& Siklus Material - Material Resources \& Cycle (MRC), (5) Kualitas Udara \& Kenyamanan Udara Dalam Ruang - Indoor Air Health \& Comfort (IHC), (6) Manajemen Lingkungan Bangunan - Building \& Enviroment Management (BEM).

Dari enam kategori penilaian pada greenship diatas, penelitian ini difokuskan pada kategori Material Resources and Cycle (MRC) atau sumber dan siklus material karena berdasarkan data World Green building Council di seluruh dunia, bangunan menggunakan 25\% produk kayu, dan 40-50\% penggunaan bahan mentah untuk pembangunan dan pengoperasiannya.

Sumber dan siklus material memiliki beberapa kriteria yaitu MRC P. Fundamental Refrigerant, MRC.1. Penggunaan Gedung dan Material Bekas (Building and Material Reuse), MRC.2. Material Ramah Lingkungan (Environ-mentally Friendly Material), MRC.3. Penggunaan Refrigeran tanpa ODP (Non ODS Usage), MRC.4. Kayu Bersertifikat (Certified Wood), MRC.5. Material Prafabrikasi (Prefab Material), MRC.6. Material Regional (Regional Material)[7].

Tabel 1. Sumber dan Siklus Material Greenship GBCI

\begin{tabular}{|c|c|c|c|}
\hline \multicolumn{4}{|c|}{ Sumber dan Siklus Material (Material Resources and Cycle-MRC) } \\
\hline MRC P & Fundamental Refrigerant & $\mathrm{P}$ & \multirow{7}{*}{$\begin{array}{c}1 \text { kriteria } \\
\text { Prasyarat: } 6 \\
\text { Kriteria kredit }\end{array}$} \\
\hline MRC 1 & $\begin{array}{l}\text { Penggunaan Gedung dan Material Bekas (Building } \\
\text { Reuse) }\end{array}$ & 2 & \\
\hline MRC 2 & $\begin{array}{l}\text { Material Ramah Lingkungan } \\
\text { (Environmentally Friendly Material) }\end{array}$ & 3 & \\
\hline MRC 3 & $\begin{array}{l}\text { Penggunaan Refrigeran tanpa ODP } \\
\text { (Non ODS Usage) }\end{array}$ & 2 & \\
\hline MRC 4 & Kayu Bersertifikat (Certified Wood) & 2 & \\
\hline MRC 5 & $\begin{array}{l}\text { Material Prafabrikasi } \\
\text { (Prefab Material) }\end{array}$ & 3 & \\
\hline \multirow[t]{2}{*}{ MRC 6} & $\begin{array}{l}\text { Material Regional } \\
\text { (Regional Material) }\end{array}$ & 2 & \\
\hline & Total Nilai Kategori MRC & 14 & $13.9 \%$ \\
\hline
\end{tabular}

Sumber : Rachmaniatus, 2016

\section{MRC P.}

\section{Fundamental Refrigerant}

Mencegah pemakaian bahan dengan potensi merusak ozon yang tinggi, yaitu tidak menggunakan chloro fluoro-carbon (CFC) sebagai refrigeran dan halon sebagai bahan pemadam kebakaran.

\section{MRC.1.}

Penggunaan Gedung dan Material Bekas (Building and Material Reuse)

Menggunakan material bekas bangunan lama dan/atau dari tempat lain untuk mengurangi penggunaan bahan mentah yang baru, sehingga dapat mengurangi limbah pada pembuangan akhir serta memperpanjang usia pemakaian suatu bahan material. 
MRC.2.

Material Ramah Lingkungan (Environ-mentally Friendly Material)

Mengurangi jejak ekologi dari proses ekstraksi bahan mentah dan proses produksi material. Yaitu dengan menggunakan material yang memiliki sertifikat sistem manajemen ling-kungan pada proses produksinya, menggunakan material yang merupakan hasil proses daur ulang, atau menggunakan material yang bahan baku utamanya berasal dari sumber daya terbaharukan.

MRC.3.

Penggunaan Refrigeran tanpa ODP (Non ODS Usage)

Menggunakan bahan yang tidak memiliki potensi merusak ozon. Yaitu dengan tidak menggunakan bahan perusak ozon (BPO) pada seluruh sis-tem pendingin bangunan.

MRC.4.

Kayu Bersertifikat (Certified Wood)

Menggunakan bahan baku kayu yang dapat dipertanggungjawabkan asal-usulnya untuk melindungi kelestarian hutan. Yaitu dengan menggunakan bahan material kayu yang bersertifikat legal sesuai dengan Peraturan Pemerintah tentang asal kayu, atau bersertifikasi dari pihak Lembaga Eko-label Indonesia (LEI) atau Forest Stewardship Council (FSC).

\section{MRC.5.}

Material Prefabrikasi (Prefab Material)

Meningkatkan efisiensi dalam penggunaan material dan mengurangi sampah konstruksi. Yaitu dengan menggunakan material modular atau prefabrikasi.

\section{MRC.6. Material Regional (Regional Material)}

Mengurangi jejak karbon dari moda transportasi untuk distribusi dan mendorong pertumbuhan ekonomi dalam negeri. Yaitu dengan menggunakan material yang lokasi asal bahan baku utama dan pabrikasinya berada dalam radius $1.000 \mathrm{~km}$ dari lokasi proyek atau masih berada dalam wilayah Republik Indonesia [8].

\subsection{Reuse Material Container (Peti Kemas)}

Dimulai dari tahun 1977, di Amerika Serikat studi penggunaan kontainer sebagai bahan bangunan sudah diwacanakan terutama untuk bangunan militer. Di Indonesia, penggunaan kontainer sebagai bangunan diperkirakan dilakukan sekitar tahun 2014, tetapi fenomenanya menjadi semakin mengemuka sejak tahun 2017 sampai sekarang [9].

Dari sudut pandang arsitektur, kontainer merupakan ruang tertutup pada enam sisi yang mirip dengan ruang tertutup oleh atap, lantai dan tembok. Dalam kondisi tersebut, kontainer memiliki potensi dan kemungkinan dalam segi arsitektur. Selain memiliki kemampuan untuk menyimpan barang yang akan didistribusikan, kini kontainer dapat digunakan sebagai pelengkap arsitektur. Peti kemas yang biasanya digunakan untuk tujuan komoditas, dapat digunakan untuk menampung kegiatan manusia. Kotak pengangkutan berbahan dasar metal ini memiliki ukuran yang cukup besar yaitu panjang hingga 6 - 12 meter, lebar 2,5 meter dan tinggi 2,5 meter. Selain itu, kelebihan peti kemas ini sendiri dapat ditumpuk hingga dua belas susun dan memiliki ketahanan atau kekuatan yang tinggi [10].

Peti kemas bekas pakai merupakan material yang dapat digunakan kembali (reuse) dan didaur ulang (recycle) sehingga dapat dikatakan peti kemas bekas pakai ini bukan termasuk limbah yang dapat merusak lingkungan. Keberadaannya cukup melimpah dan mudah untuk dibongkar pasang menjadikan peti kemas bekas pakai ini hemat energi dan ramah lingkungan. Peti kemas bekas pakai ini memiliki modul yang sama, jumlahnya banyak, mudah dirangkai dan dengan harga yang relatif murah menjadikan material ini menjadi altenatif ruang yang hemat biaya, unik dan inovatif [11].

Kontainer terbuat dari material baja corten yang memiliki struktur yang kuat dan memiliki beberapa kelebihan yaitu mudah dipindahkan dan dapat dialihfungsikan menjadi ruangan. Namun material ini 
sekaligus mempunyai kekurangan karena merupakan penghantar panas yang baik sehingga memerlukan insulasi untuk menghambat panas supaya kenyamanan thermal dapat dicapai bagi penggunanya [12].

\section{METODOLOGI}

Dalam penelitian ini, metode yang digunakan adalah metode kualitatif dengan mengumpulkan informasi aktual secara rinci dan sistematis, fakta atau karakteristik populasi tertentu atau bidang tertentu berupa ciri, sifat, keadaan, atau gambaran dari kualitas objek yang diteliti.

Pendekatan studi dilakukan dengan konsep ramah lingkungan dan greenship pada bangunan yang menekankan pada ategori Material Resources and Cycle (MRC) atau sumber dan siklus material. Pengumpulan data teori dan literatur berupa pengetahuan mengenai hubungan teori dan pembahasan perancangan arsitektur bangunan yang ramah lingkungan seperti Greenship untuk Gedung Baru Versi 1.1 dan Greenship untuk Bangunan Baru Versi 1.2. Data tersebut kemudian dibandingkan dengan data yang didapat pada saat observasi secara langsung ke lapangan. Adapun prosedur penelitian mencakup kegiatan persiapan, pengumpulan data baik literatur maupun data lapangan. Kegiatan dilanjutkan dengan pengolahan dan analisa data berdasarkan aspek greenship GBCI dengan menekankan siklus dan sumber material untuk mendapatkan kesimpulan penilaian.

\section{HASIL DAN PEMBAHASAN}

\subsection{Kajian Obyek Penelitian: Café Day N Nite Bandung}

Cafe Day $n$ Nite adalah sebuah bangunan yang berada di Perumahan Pramesta Resort Town, tepatnya di Jalan Akaza Utama No. 9, Mekarwangi, Lembang, Kabupaten Bandung Barat, Jawa Barat, Indonesia. Bangunan ini merupakan bangunan komersial yang difungsikan sebagai restoran atau cafe yang menunjang kegiatan di dalam Perumahan Pramesta maupun kegiatan rekreasi. Dikelola oleh PT. Lembang Permata Recreation Estate, bangunan ini dirancang oleh Arsitek Michael Brohet, dibangun diatas lahan seluas 2 hektar dengan luas bangunan 400 meter persegi .

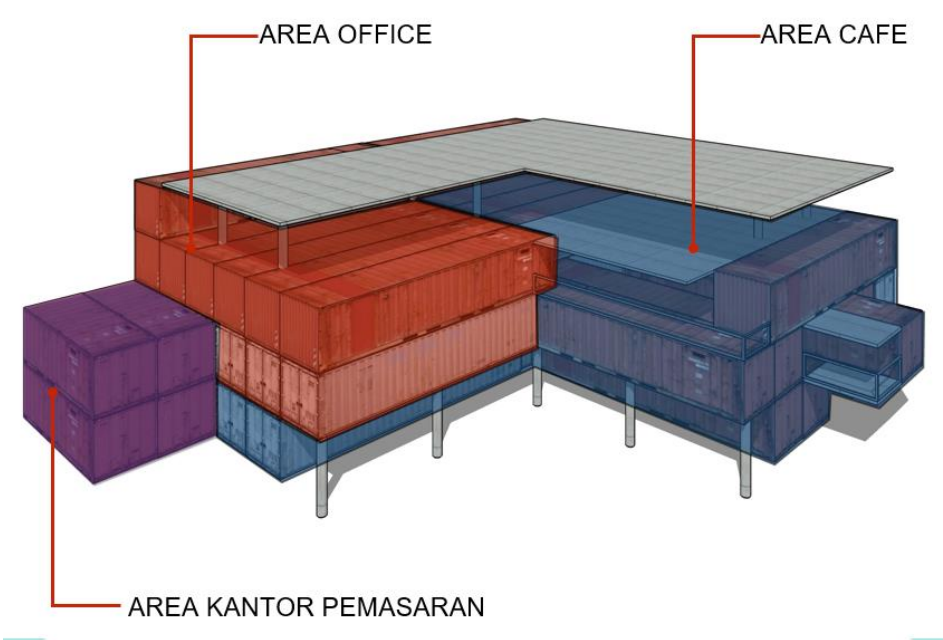

Gambar 1 Ilustrasi 3D Café Day n Nite

(Sumber : Hasil Analisis Gambar 3D Cafe Day n Nite, 2019, diolah) 
Cafe Day n Nite ini berhasil menarik perhatian karena memiliki konsep menggunakan 34 tumpukan kontainer bekas dengan usia \pm 10 tahun yang diambil dari Pelabuhan Tanjung Priok dengan bangunan yang berdiri di tengah-tengah rimbunnya pepohonan dan dikemas dalam sebuah bentuk arsitektur modern minimalis yang belum ada di Kota Bandung saat itu

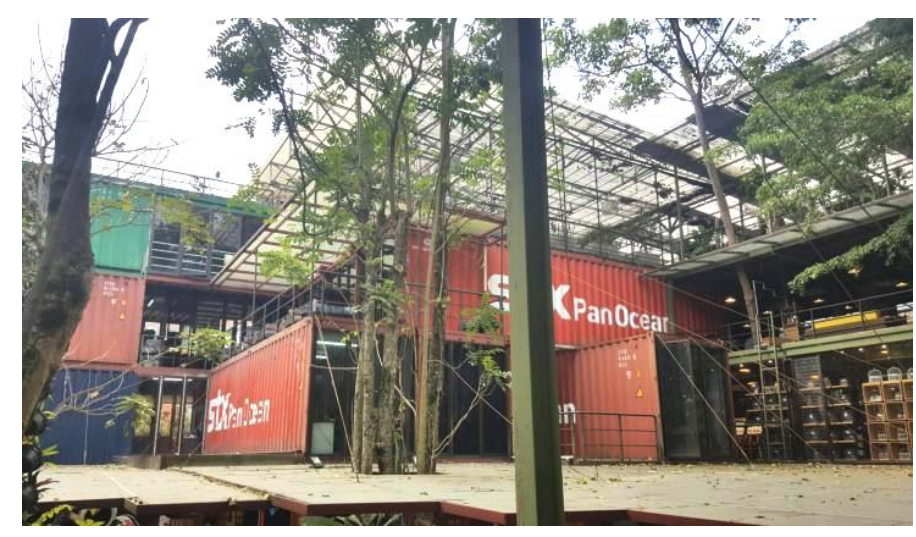

Gambar 2 Café Day n Nite

(Sumber : Hasil Survey, November 2018)

Kontainer tersebut digunakan secara utuh tanpa dibongkar pasang terlebih dahulu dengan mengambil ukuran high cube yakni luas $12 \mathrm{~m}^{2}$ dan memiliki tinggi 3 meter. Selain itu, penggunaan kontainer sebagai bangunan semi permanen dan konsep open air serta didukung dengan lingkungan sekitar yang berudara sejuk, menghasilkan suasana dan atmosfer yang unik dan alami.

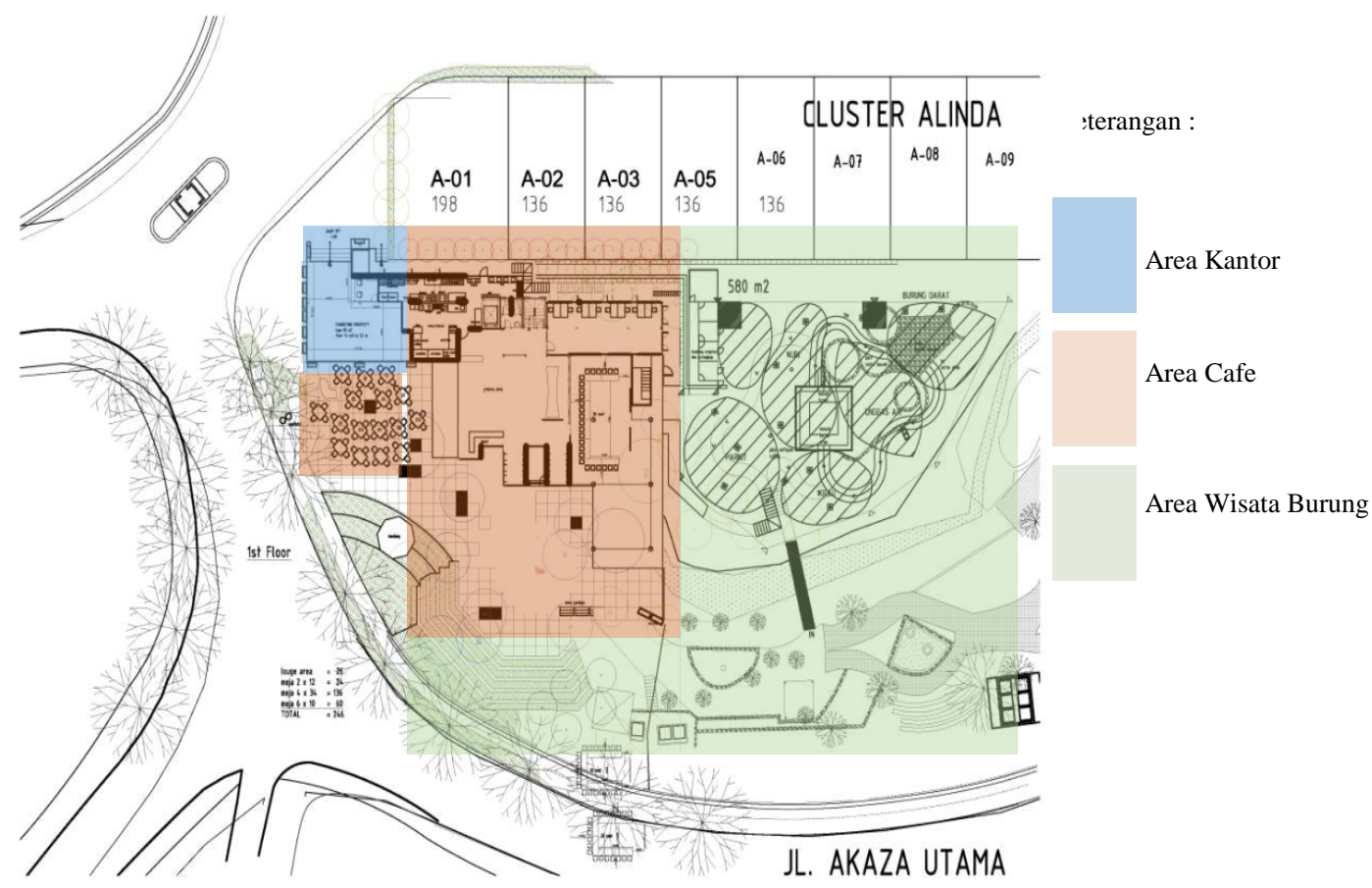

Gambar 3. Site Plan Cafe Day n Nite

(Sumber : Dokumen Gambar Kerja Cafe Day $n$ Nite, diolah) 


\subsection{Analisis Café Day N Nite Terhadap Kriteria Sustainable Building Menurut Sumber dan Siklus Material Greenship GBCI}

\subsubsection{Fundamental Refrigerant}

Fundamental Refrigerant merupakan kriteria prasyarat dalam sistem rating Greenship dengan tolak ukur tidak menggunakan chloro fluoro-carbon (CFC) sebagai refrigeran dan halon sebagai bahan pemadam kebakaran. Dengan tujuan penilaian untuk mencegah bahan dengan potensial merusak ozon yang tinggi.

Pada studi kasus penelitian ini yaitu Café Day n Night, cafe ini menggunakan refrigrant berupa freezer merek Gea, showcase merek Sansio dan Aqua yang masing masing memiliki ODP $=0$. Sebagai bahan pemadam kebakaran menggunakan tabung pemadam kebakaran yang hanya mengandung $\mathrm{CO} 2$.
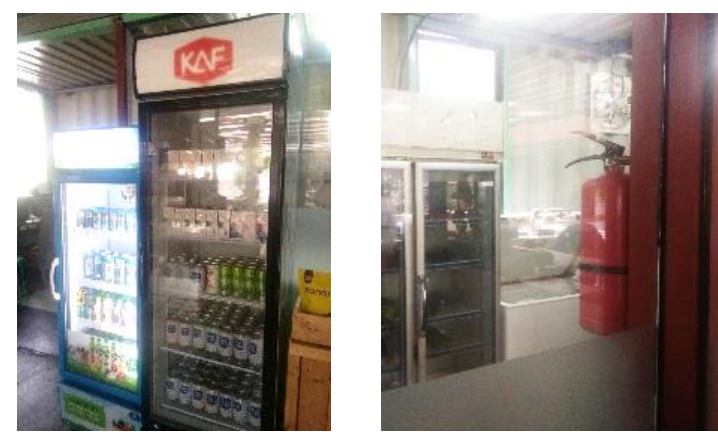

Gambar 4. Showcase Cooler Sansio dan Showcase Cooler Aqua (Sumber : Hasil Survey, November 2018)

\subsubsection{Penggunaan Gedung dan Material Bekas (Building and Material Reuse)}

Penggunaan kembali material dari gedung (building and material reuse) merupakan kriteria pada greenship GBCI dalam menggunakan material bekas dan mengurangi limbah pada pembuangan akhir serta memperpanjang usia pemakaian suatu bahan material.

Arsitek dan pihak - pihak yang terkait dalam pembangunan Café Day n Nite memiliki target yang sama dengan kriteria greenship GBCI tersebut yakni dengan reuse material atau menggunakan kembali peti kemas yang sudah tidak terpakai yang masih memiliki kualitas bagus dan aman saat dimanfaatkan sebagai bagian dari struktur utama bangunan.

Tak hanya sebagai struktur utama, peti kemas juga diterapkan sebagai fasad bangunan karena tidak lagi dilapisi oleh material lainnya sehingga material dan bentuk asli kontainer tereskpos secara jujur sehingga menjadikan bangunan ini mempunyai nilai estetika tersendiri yang unik dan menarik.

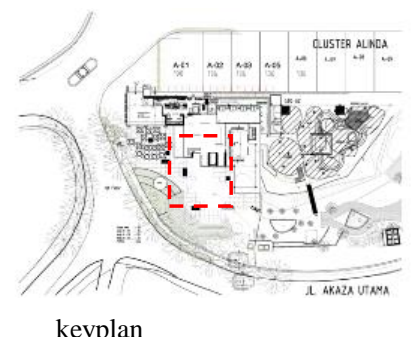

keyplan

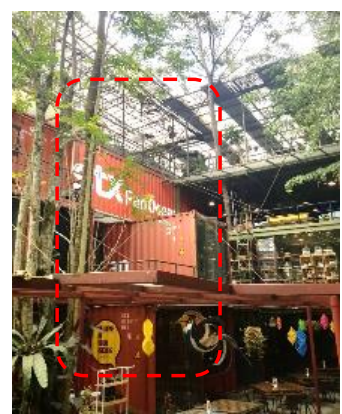

Gambar 5. Fasad depan Cafe Day n Nite (Sumber : Hasil Survey, November 2018) 


\subsubsection{Material Ramah Lingkungan (Environmentally Friendly Material)}

Material ramah lingkungan merupakan kriteria dari aspek greenship GBCI dengan tujuan untuk mengurangi jejak ekologi dari proses ekstraksi bahan mentah dan proses produksi material. Tolak ukur yang dipakai yakni menggunakan material yang memiliki sertifikat sistem manajemen lingkungan pada proses produksinya minimal bernilai $30 \%$ dari total biaya material. Tak hanya itu, dengan menggunakan material yang merupakan hasil proses daur ulang minimal bernilai $5 \%$ dari total biaya material. Bangunan ini menggunakan material yang bahan baku utamanya berasal dari sumber daya terbarukan dengan masa panen jangka pendek.

Pada tahap pelaksanaan dibutuhkan material ramah lingkungan untuk mengurangi jejak ekologi dari proses ekstraksi bahan mentah dan proses produksi material seperti yang disebutkan pada tujuan dari kriteria material ramah lingkungan. Oleh karena itu, kriteria material ramah lingkungan dapat dikatakan sesuai dengan mengoptimalkan penggunaan bahan baku bangunan meskipun penggunaannya belum sepenuhnya dilaksanakan pada proyek Café Day n Nite Bandung.

Kriteria material ramah lingkungan pada bangunan Café Day $n$ Nite Bandung ini telah menggunakan material-material yang ramah lingkungan dalam proses pembelian, keunggulan material, maintance, dan waktu umur yang lama pada tahap pelaksanaan dan pemeliharaannya. Meskipun demikian pembangunan Cafe Day $n$ Nite ini masih belum memenuhi persyaratan greenship dari segi manajemen total biaya pembangunan.
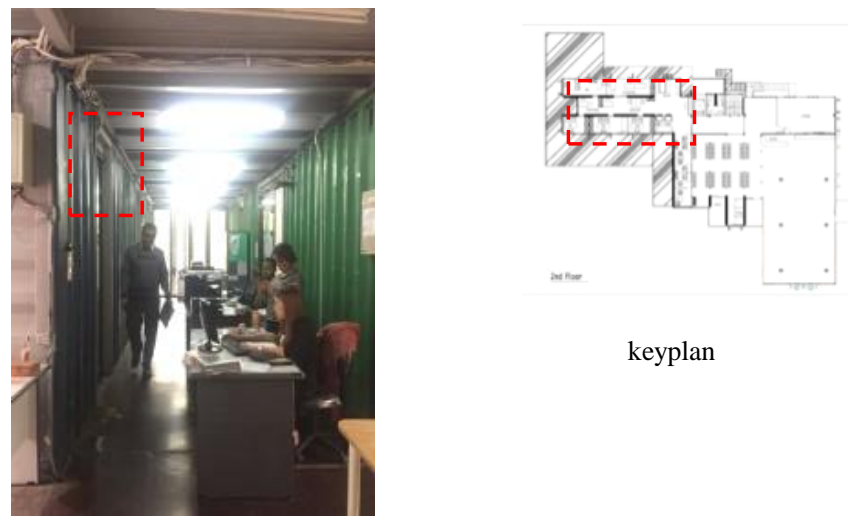

Gambar 6. Salah satu bagian dinding Cafe Day $n$ Nite yang menggunakan material bekas (Sumber : Hasil Survey, November 2018)

\subsubsection{Penggunaan Refrigeran Tanpa ODP (Non ODS Usage)}

Tolak ukur dalam kriteria yang keempat ini adalah tidak menggunakan bahan perusak ozon pada seluruh sistem pendingin gedung dengan tujuan menggunakan bahan yang tidak memiliki potensi merusak ozon. Menurut Peraturan Menteri Perindustrian No.33/MIND/PER/4/2007 tentang larangan memproduksi barang yang menggunakan bahan perusak lapisan ozon,

Pada Café Day $n$ Night ini tidak menggunakan refrigerant sebagai pendingin ruangan karena lokasi café berada di dataran tinggi sehingga suhu di lokasi café rata-rata nyaman lebih dingin dari pada suhu di perkotaan. Oleh karena itu, konsep café ini menggunakan penghawaan alami secara maksimal dan tidak menggunakan pendingin ruangan buatan sama sekali.

\subsubsection{Kayu Bersertifikat (Certified Wood)}

Tujuan dalam kriteria ini adalah menggunakan bahan baku kayu yang dapat dipertanggung jawabkan asal-usulnya untuk melindungi kelestarian hutan. Dengan tolak ukur menggunakan bahan material kayu yang bersertifikat legal sesuai dengan Peraturan Pemerintah tentang asal kayu (seperti faktur angkutan kayu olahan/FAKO, sertifikat perusahaan, dan lain-lain) dan sah terbebas dari perdagangan 
kayu ilegal sebesar $100 \%$ biaya total material kayu. Kemudian, penggunaan kayu bersertifikat ini dikatakan legal, jika 30\% dari butir di atas menggunakan kayu bersertifikasi dari pihak Lembaga Ekolabel Indonesia (LEI) atau Forest Stewardship Council (FSC)

Material kayu yang digunakan pada café ini yaitu tergolong sedikit, karena hanya digunakan sebagai elemen interior seperti furniture meja dan kursi. Kayu yang digunakan sebagai meja yaitu berasal dari pohon yang ditebang pada saat pembersihan site pada lokasi café ini. Sehingga kayu-kayu yang digunakan pada café ini bersifat legal. Data ini diperkuat berdasarkan hasil wawancara dengan pihak café, tetapi kayu ini tidak bersertifikasi dari pihak LEI atau FSC sehingga tidak memenuhi kriteria pada tolok ukur poin ke 2 .

\subsubsection{Material Prefabrikasi (Prefab Material)}

Prefabrication (prefabrikasi) adalah industrialisasi metode konstruksi di mana komponenkomponennya diproduksi secara massal dirakit (assemble) dalam bangunan dengan bantuan crane dan alat-alat pengangkat dan penanganan yang lain. Precast Structural Components (Komponen Struktur Pracetak), alternatifnya dibuat untuk bangunan pada site tertentu. Pelaksanaan material dan pekerjaan pabrikasi dalam lingkup Café Day n Nite, yaitu material prefabrikasi kontainer atau peti kemas, baja WF, dan plat lantai beton precast.

Penggunaan material precast beton pada Café Day n Nite diaplikasikan pada bagian lantai bangunan khususnya pada area makan outdoor lantai satu. Lantai beton precast dicetak langsung dilapangan atau cast in site dengan ukuran 1,2 meter x 1,2 meter, sesudah kering lalu dipasang manual pada area yang direncanakan. Penggunaan material Prefabrikasi Baja pada Café Day n Nite diaplikasikan pada bagian kolom dan balok bangunan khususnya pada bagian café buffy dan toko oleh-oleh. Material utama prefabrikasi pada bangunan Café Day $n$ Nite yaitu material reuse container atau peti kemas yang diaplikasikan pada bagian hampir seluruh bangunan, material kontainer dipertahankan kondisi asli seperti tidak dicat ulang maupun ditambahkan insulasi panas.

Desain yang menggunakan material modular atau prefabrikasi (tidak termasuk equipment) sebesar $30 \%$ dari total biaya material.

Biaya Material Prefabrikasi :

A.Pekerjaan Beton : Rp. 43.540 .000

- Atap dak beton

- Lantai Beton pada Area Makan

B. Baja WF : Rp. 428.794 .000

C. Petikemas : Rp. 1.020.000.000

Total Biaya : : Rp. 4.000.000.000

$30 \%$ T. Biaya : Rp. 1.200.000.000

Total Biaya Material Prafabrikasi : Rp. 1.546.334.000

Tabel 2. Presentase Penggunaan Material di Cafe Day $n$ Nite

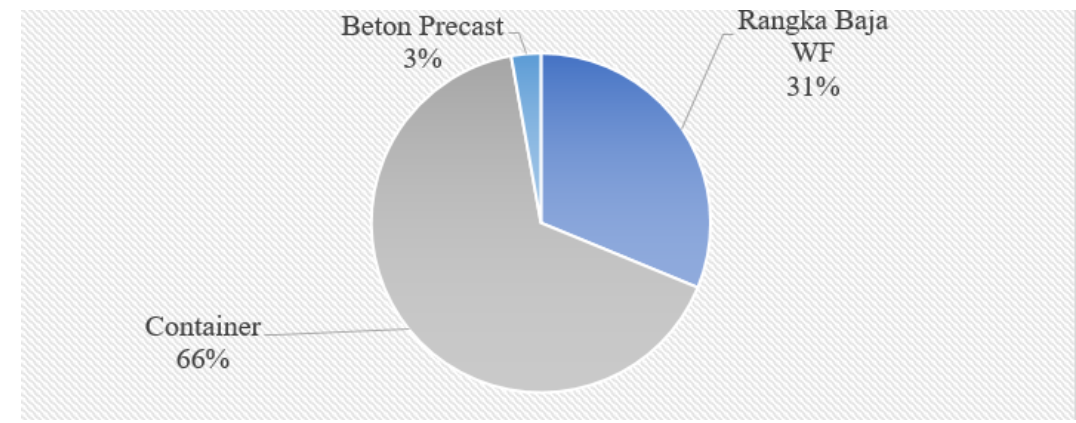

Sumber : Hasil Analisis, 2019 
Nilai biaya material yang didapatkan pada kriteria material prefabrikasi sebesar Rp. 1.546.334.000 dan nilai tersebut telah memenuhi dari $30 \%$ total biaya material sebesar kurang lebih Rp. 4.000.000.000 yang disyaratkan greenship GBCI.

Berdasarkan nilai tersebut kriteria material prefabrikasi aspek sumber dan siklus material pada bangunan Café Day $n$ Nite dinyatakan sudah sesuai dengan nilai biaya material. Penilaian dalam green construction untuk kriteria material prefabrikasi dibutuhkan, karena pelaksanaan material prefabrikasi dapat memperpendek jarak pengambilan material, meningkatkan efisiensi dalam konstruksi, mudah dalam pemantauan, mengurangi kebutuhan tenaga kerja manusia, dan mengurangi jejak karbon.

\subsubsection{Material Regional (Regional Material)}

Material regional (regional material) adalah kriteria terakhir pada aspek sumber dan siklus material. Tujuan pelaksanaan kriteria ini adalah untuk mengurangi jejak karbon dari modal transportasi dalam distribusi dan mendorong pertumbuhan ekonomi dalam negeri.

Pada proyek pelaksanaan Cafe Day $n$ Nite ini menggunakan material yang lokasi asal bahan baku utama dan pabrikasinya berada di dalam radius $1.000 \mathrm{~km}$ dari lokasi proyek minimal bernilai $50 \%$ dari total biaya material. Kemudian, bangunan ini menggunakan material yang lokasi asal bahan baku utama dan pabrikasinya berada dalam wilayah Republik Indonesia bernilai minimal 80\% dari total biaya material.

Penggunaan material kontainer atau peti kemas pada Café Day $n$ Nite diambil atau dikirim dari lokasi Pelabuhan Tanjung Priok, Jakarta Utara yang jarak tempuh \pm 200 kilometer melalui jalur tol, yang artinya bahan baku atau material pabrikasinya masih berada di dalam radius 1000 kilometer dari lokasi proyek, oleh karena itu bangunan Café Day n Nite memenuhi syarat.

Tabel 3. Sumber dan Siklus Material Greenship GBCI

\begin{tabular}{clc}
\hline Sumber dan Siklus Material (Material Resources and Cycle-MRC) & \\
\hline MRC P & Fundamental Refrigerant & $\mathrm{P}$ \\
\hline MRC 1 & $\begin{array}{l}\text { Penggunaan Gedung dan Material Bekas } \\
\text { (Building and Material Reuse) }\end{array}$ & 2 \\
\hline MRC 2 & $\begin{array}{l}\text { Material Ramah Lingkungan } \\
\text { (Environmentally Friendly Material) }\end{array}$ & 1 \\
\hline MRC 3 & $\begin{array}{l}\text { Penggunaan Refrigeran tanpa ODP } \\
\text { (Non ODS Usage) }\end{array}$ & 2 \\
\hline MRC 4 & Kayu Bersertifikat & 1 \\
\hline MRC 5 & Material Prafabrikasi & 3 \\
\hline MRC 6 & Material Regional & Total \\
\hline & Poin Seharusnya & 11 \\
\hline
\end{tabular}

Sumber : Hasil Analisis, 2019

\section{SIMPULAN}

Hasil analisa dari poin penilaian Sumber dan Siklus Material pada kriteria Greenship GBCI disimpulkan bahwa Café Day $n$ Nite sudah memenuhi beberapa kriteria green building dan hanya 
beberapa kriteria saja yang tidak memenuhi greenship GBCI secara keseluruhan. Dengan demikian, bangunan Café Day $n$ Nite ditinjau dari penilaian greenship GBCI pada Siklus dan Sumber Material hanya mempunyai 11 poin dari 14 poin yaitu sebesar $79 \%$.

\section{DAFTAR PUSTAKA}

[1] Peraturan Menteri Negara Lingkungan Hidup nomor 08 tahun 2010 tentang Kriteria dan Sertifikasi Bangunan Ramah Lingkungan.

[2] Lembaga KONSIL BANGUNAN HIJAU INDONESIA atau GREEN BUILDING COUNCIL INDONESIA (GBC Indonesia) https://www.gbcindonesia.org/

[3] Departemen Pekerjaan Umum (2008),"Keputusan Menteri Dalam Negeri Nomor: PRT / M / 24 / XII / 2008 tentang Pedoman Pemeliharaan dan Perawatan Bangunan Gedung; Jakarta: Direktorat

[4] Priatman, Jimmy. (2002). "Energi-Efficient Architecture, Paradigma dan Manifestasi Arsitektur Hijau", Dimensi Journal of Architecture and Built Environment Vol 30 No 2.

[5] Utami, Fitriyah Nurul Hidayati, Kaswanto, Akhmad Arifin Hadi (2008)." Penerapan Konsep Bangunan Ramah Lingkungan Melalui Konstruksi Green Panel sebagai alternatif Peningkatan Kenyamanan Dalam Ruang”, Jurnal Ilmu Pertanian Indonesia, hlm 204-2112.

[6] Redaksi Tata Ruang Indonesia (BUTARU)(2018)," Green Building A Sustainable Concept for Construction Development in Indonesia"; (http://tataruang.bpn.go.id/Berita/Detail/2712) diakses tanggal 10 Oktober 2018.

[7] Green Building Council Indonesia (GBCI). (2018). Tentang GBC Indonesia; http://www.gbcindonesia.org > diakses tanggal 10 Oktober 2018

[8] Rachmaniatus, Dewi. (2016).'Penerapan Aspek Green Material Pada Kriteria Bangunan Ramah Lingkungan Di Indonesia; Tesis Magister; Sekolah Arsitektur Perencanaan dan Pengembangan Kebijakan; ITB

[9] Harisah, Afifah. (2018)." Munculnya Arsitektur Kontainer di Makassar dan Sekitarnya, "Manifesto Arsitektur Hijau". Seminar Ikatan Peneliti Lingkungan Binaan Indonesia (IPLBI) 3, B007-016, Oktober 2018.

[10] Ikhsanudin, Khabib; (2017)."Dasar Program Perencanaan dan Perancangan Arsitektur (DP3A) Tanjung Emas Container Apartment “. Bahan kuliah Program Studi Strata I; Fakultas Teknik Arsitektur; Surakarta.

[11] Fitrianto, Ekan, Ashadi, Lutfi Prayogi. (2017), “Penerapan Konsep Reuse Peti Kemas pada Hunian dan Perkantoran di Kawasan Bongkar Muat Pelabuhan",. Jurnal Arsitektur Purwarupa Volume 1 no 1, Maret 2017.

[12] Lie, Devi Sugiarto, Yusita Kusumarini, Meirina Kuncahyowati. (2019).’Perancangan Alih Fungsi Kontainer Menjadi Modul Ruang Komersial "Fasilitas Makan dan Minum", Jurnal Intra Vol.7 NO 2 hal. 328-334. 